Arab Univ. J. Agric. Sci., Ain Shams Univ., Cairo, Egypt

29(2), 753-763, 2021

Website: http://ajs.journals.ekb.eg

DOI: 10.21608/ajs.2021.68479.1351

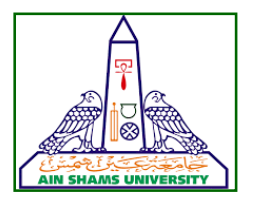

\title{
Assessment of Some Essential Oils and Their Mixtures as Material Repellents Against Adults of The Confused Flour Beetle, Tribolium confusum (Du Val) (Coleoptera: Tenebrionidae)
}

\author{
Salwa S Pasha* \\ Plant Protection Department, Faculty of Agriculture, Fayoum University, Egypt \\ *Corresponding author: ssb01@fayoum.edu.eg
}

Received 18 March, 2021

Accepted 2 June, 2021

\section{Abstract}

Repellency of the six essential oils (EOs), Clove (Eugenia aromaticum), Aloe (Aloe vera), Lemon (Citrus limon), Camphor (Eucalyptus camaldulensis), Mint (Mentha spicata), Marjoram (Origanum vulgare) were evaluated against adult of the confused flour beetle Tribolium confusum, by allowing adults to choose between untreated filter paper halves with 1 $2 \mathrm{~g}$ white flour or treated with different concentrations of the oils and their mixture at three different exposure times. In individual oils experiments, Eucalyptus camaldulensis was found to be the best effective of repellent efficacy, followed by Mentha spicata and Eugenia aromaticum. Citrus limon and Aloe vera have moderate repellent efficacy. Results of combination effective showed that mixtures' repellant activity. It has been shown that the most powerful mixture of Clove + Mint repels activity against adults with Lemon + Aloe, Lemon + Marjoram, Lemon + Mint, and Mint + Aloe during the entire exposure period, while Lemon + Camphor and Camphor + Mint lost repellent activity after 24 hours.

Keywords: Tribolium confusum, Essential oils, Oils combination, Repellency

\section{Introduction}

The confused flour beetle, Tribolium confusum (du val), known as "bran bugs," is secondary pest commonly found infesting stored products. Milled grain products are primarily under attack, but not the undamaged whole grain (Bennett 2003).

Specimens of beetles have been found in a variety of stored products, such as cereals, oats, dried fruits, peas, oats, milk powder, etc (Mediouni Ben Jemâa et al 2012, Pugazhvendan et al 2009, Bennett 2003). These beetles in infested flour also hitchhike into the home and may multiply into large populations. In warehouses and in factories manufacturing starch goods, it is especially injurious. Larvae-infested flour has an agreyish color and a tendency to become mouldy (Bennett 2003).

$T$. confusum populations in the storage bins, milling, formulation and pelleting sites were located (Trematerra and Sciarretta 2004). Their develop resistance to some of the few chemical options due to complicates management and Cause significant economic loss (Holloway et al 2020, Isman 2020). The chemical compounds, including both fumigants and contact insecticides, are used on food grains to control storage insects (Jeanmart et al 2016). Due to certain drawbacks related to these chemicals, such as residual effects, the poten- 
tial for toxicity and the inherent expense of applying conventional insecticides, successful control measures are highly important, furthermore, pesticides resistance (Daglish 2004, Sylvia et al 2009). Eight strains of red flour beetle, T. castaneum all strains were resistant to Malathion and one strain was resistant to phosphine (Zetter and Cuperus 1990).

Might be using aromatic plants as intercrops in agroecosystems to biologically control insect pests (Tang et al 2013). For stored products, plant-obtained materials such as essential oils (EOs) are sources of protection (Shimomura et al 2019). As an alternative to synthetic repellents, plant essential oils (EOs) and botanical insecticides have been used widely (Lee 2018 and Isman 2006). Essential oils are consisted the various monoterpenoids and other molecules shown properties for pests control agents, it work as insecticidal, repellent and antifeedant (Jeyasankar et al 2016, Ukeh et al 2009, López et al 2008).

(Olivero-Verbel et al 2013, Nerio et al 2009) repellency effective properties of Colombian aromatic plants and their molecules contained in EOs have also demonstrated better action than the commercial repellent IR3535 against $T$. castaneum. Strong effects against $T$ Castaneum of the repellent and larvicidal efficacy of essential oils. (Jeyasankar et al 2016) very strong repellent activity of four ingredients as contact and fumigant agents were obtained from Laurelia sempervirens and Drimys winteri the bark and leaves against $T$. castaneum (Zapata and Smagghe 2010). Seven compounds were extracted from essential oils of Alpinia zerumbet (Pers.), (camphor, m-cymene, eucalyptol, o-cymene, borneol, camphene, eucalyptol and eucalyptol) were shown different levels as insecticidal and repellent efficacy towards $T$. Castaneum (Feng et al 2021). The essential oils and components of Aframomum melegueta (K. Schum) and Zingiber officinale (Roscoe) may be ideal as safety fumigants and repellents (Ukeh and Sylvia 2011).

(Myrtaceae) usefully applied to control storage pests (Zandi-Sohani et al 2013). About the genus Aloe L majority opinion ratios suggest that the most popular uses of Aloe are in medicine and pest management against arthropods and invertebrates, (Asphodelaceae) comprising 548 recognized species (Grace et al 2009). The extracts of the Lamiaceae family have repellents and anti-feedant action (Pavela 2004). Essential oils contain many chemical compounds that cause many metabolic disorders, besides repellent and lethal effects (Deb and Kumar 2020).

The study aims to find safe alternatives to prevent infestation with flour beetles without the need to use the chemical insecticides. Thus, the research paper verified the effectiveness of some essential oils on the confused beetle individually, as well as evaluated after mixing them.

\section{Materials and Methods}

The experiment was undertaken on the adults of the confused flour beetle, Tribolium confusum (du val) (Coleoptera: Tenebrionidae).

\subsection{Insects culture}

Source of $T$. confusum was collected from infested whole wheat flour from the home kitchen in fayoum governorate, Egypt. It was brought to the laboratory and put it in a plastic container of $26 \times 29 \mathrm{~cm}$ containing whole wheat flour under the laboratory temperature $20 \pm 2^{\circ} \mathrm{C}$. Adults of $T$. confusum were used in subsequent experiments were separated by a sieve.

\subsection{Essential oils sources}

The six essential oils, Clove Eugenia aromaticum (L.) Baill, Myrtaceae, Aloe Aloe vera (L.) Burm.f., Asphodelaceae, Lemon Citrus limon (L.) Osbeck, Rutaceae, Camphor Eucalyptus camaldulensis Dehnh, Myrtaceae, Mint Mentha spicata L, Lamiaceae, Marjoram Origanum vulgare L, Lamiaceae, were purchased from local market (spice dealer, a store that 


\section{Assessment of Some Essential Oils and Their Mixtures as Material Repellents Against Adults of The Confused Flour Beetle, Tribolium confusum (Du Val) (Coleoptera: Tenebrionidae)}

sells spices, medicinal plants, and essential oils) at Fayoum Governorate, Egypt, from Elshatby, El-captain and other companies extracting oils, herbs and cosmetics, Cairo, Egypt, which authorized by the Egyptian Ministry of Health for different human uses were experimented, for used in the experiments of repellent activity against adults of $T$. confusum.

\subsection{Evaluation of insect repellence}

Repellent action in the six essential oils on adult of $T$. confusum was evaluated using the technique certified from (Jo et al 2013) with slight modifications. Using twenty insect adults per dish, a selection bioassay with three replications (dishes) was set up. The plastic dishes $(12 \mathrm{~cm}$ Length $\times 9 \mathrm{~cm}$ width) were divided into three zones.

Test solutions were made by dissolving, 10 $\mathrm{ml}$ of distilled water in different $(4,2,1,0.5$ gm) concentrations of each oil with addition 12 drop of triton emulsifier.

Mixtures of oils, The mixture test solution was prepared at a rate of $1: 1$ by dissolving 0.5 $\mathrm{g}$ of the first oil $+0.5 \mathrm{~g}$ of another oil in $10 \mathrm{ml}$ of distilled water plus 1-2 drops of tritone emulsifier.

The filter paper for Whatman No. 1 (90 $\mathrm{mm}$ ) was divided into two halves. At each concentration, half of the filter paper was submerged at the rate of three halves of the filter paper for each concentration. Distilled water + 1-2 drop triton was treated with the other filter paper half. The halves of water untreated and oil treated were fully dried for around $15 \mathrm{~min}$. Untreated halves (control) were placed in one zone. Treated halves of solution of the essential oils were placed in the other zone and put $1 \mathrm{~g}$ wheat flour on each half. The 20 unsexed adults of $T$. confusum were released in the center of the dish and then the dishes were sealed and incubated at $25 \pm 1^{\circ} \mathrm{C}$.

For each treated or untreated (control) half and diet, the number of adults present was counted after (1, 3, 24 hours) and calculated the mortality of adult if found that. By using the following equation ("Taulkader, 1944," n.d.), the data was expressed as percentage repellency $(\mathrm{PR})$ :

Percentage Repellency $(\mathrm{PR})=[\mathrm{NC}-\mathrm{NT} /$ $\mathrm{NC}+\mathrm{NT}] \times 100$

$\mathrm{NC}$ is Adult No. on the control section, NT is Adult No. on the treated section. The values were then categorized as follows $0-\mathrm{V}$ repellency classes, whereas Class $0=<0.1$, Class I $=0.1-20$, Class II = 20.1-40, Class III = 40.160 , Class IV $=60.1-80$ and Class $\mathrm{V}=80.1$ $100 \%$, respectively (McGovern 1977).

\subsection{Statistical analysis}

Relationships between concentrations of oils and recorded values of percentage repellency ( $P R$ in 3 times) were evaluated by using simple correlation (Pearson) (r), SPSS software program was used (Senedecor and Cochran 1967).

\section{Results and Discussion}

\subsection{Individual experiments of essential oils}

The repellant effective was studied at four series concentrations of six individual essential oils, against adults of $T$. confusum with three an exposure period (Table 1). Positive percentages of adults repellency (in the control section), whereas negative percentages suggest their attraction (in the treated section).

Shown (Fig 1 \& Table 1) percentage repellency of six essential oils after one hour exposure, observed it is evident that the repellant activity of the two oils of lemon and clove are significant positive correlation to the concentrations $\left(\mathrm{r}=0.98^{*} \& 0.23\right.$ respectively), as the repellant activity of both increases with increasing concentration recorded 30 and $43.33 \%$ PR respectively at $0.4 \mathrm{~g} / 1 \mathrm{ml}$. This applies to camphor oil is insignificant positive correlation $r=0.002$, the higher concentrate, it was found during subsequent periods of exposure that it carries a chronic toxicity reach to $21.7 \%$ mortality, repellent effect was strong with positive class of IV, III, I at $0.2-0.1-0.05$ $\mathrm{g} / 1 \mathrm{ml}$. 


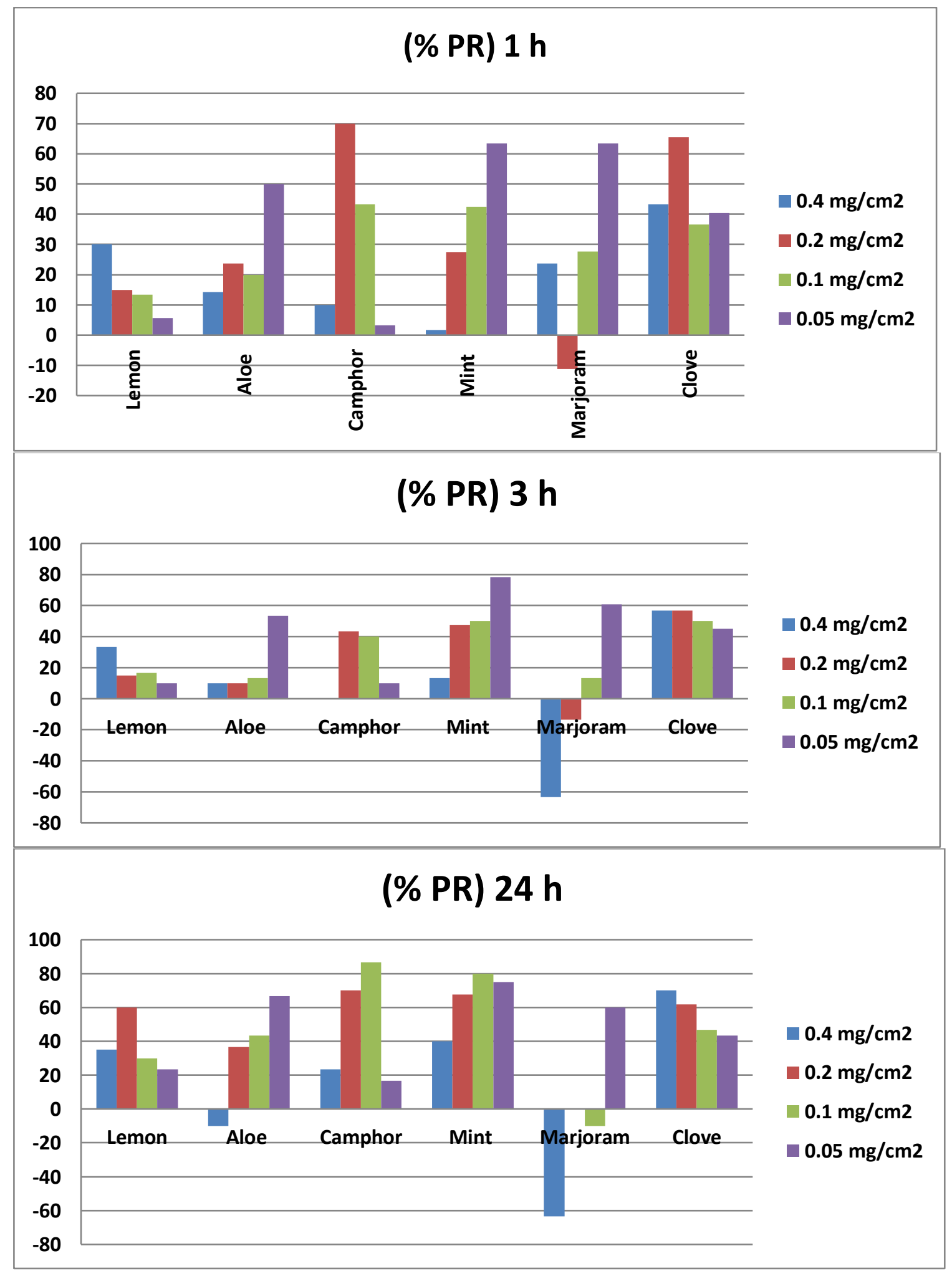

Fig 1. Percentage repellency diagrams of six essential oils against adult of T. confusum at different exposure times 
Assessment of Some Essential Oils and Their Mixtures as Material Repellents Against Adults of The Confused Flour Beetle, Tribolium confusum (Du Val) (Coleoptera:

Tenebrionidae)

Table 1. Percentage repellency of six essential oils against adult of $T$. confusum at three exposure times

\begin{tabular}{|c|c|c|c|c|c|c|c|c|c|c|}
\hline \multirow[b]{2}{*}{ Essential oils } & \multirow{2}{*}{$\begin{array}{c}\text { Conc } \\
\mathrm{mg} / \mathbf{1 m l}\end{array}$} & \multicolumn{3}{|c|}{1 Hour } & \multicolumn{3}{|c|}{3 Hours } & \multicolumn{3}{|c|}{24 Hours } \\
\hline & & $\% \mathbf{P R}^{1}$ & Class & $\begin{array}{c}\% \\
\text { Mortality } \\
\end{array}$ & $\% \mathbf{P R}$ & Class & $\begin{array}{c}\% \\
\text { Mortality } \\
\end{array}$ & $\%$ PR & Class & $\begin{array}{c}\% \\
\text { Mortality } \\
\end{array}$ \\
\hline \multirow{4}{*}{$\begin{array}{l}\text { Camphor } \\
\text { Eucalyptus } \\
\text { camaldulensis }\end{array}$} & 0.4 & 10 & I & 0 & 0 & 0 & 13.33 & 23.40 & II & 21.67 \\
\hline & 0.2 & 69.96 & IV & 0 & 43.33 & III & 0 & 70 & IV & 0 \\
\hline & 0.1 & 43.33 & III & 0 & 40 & II & 0 & 86.67 & $\mathrm{~V}$ & 0 \\
\hline & 0.05 & 3.33 & I & 0 & 10 & I & 0 & 16.67 & $\mathrm{I}$ & 0 \\
\hline \multicolumn{2}{|c|}{ Pearson (r) } & \multicolumn{3}{|c|}{0.002} & \multicolumn{3}{|c|}{-0.34} & \multicolumn{3}{|c|}{-0.15} \\
\hline \multirow{4}{*}{$\begin{array}{c}\text { Clove } \\
\text { Eugenia } \\
\text { aromaticum }\end{array}$} & 0.4 & 43.33 & III & 0 & 56.67 & III & 0 & 70 & IV & 0 \\
\hline & 0.2 & 65.55 & IV & 0 & 56.67 & III & 0 & 61.67 & IV & 0 \\
\hline & 0.1 & 36.66 & II & 0 & 50 & III & 0 & 46.67 & III & 0 \\
\hline & 0.05 & 40.35 & II & 0 & 45 & III & 0 & 43.33 & III & 0 \\
\hline \multicolumn{2}{|c|}{ Pearson (r) } & \multicolumn{3}{|c|}{0.23} & \multicolumn{3}{|c|}{0.87} & \multicolumn{3}{|c|}{$0.96^{*}$} \\
\hline \multirow{4}{*}{$\begin{array}{c}\text { Mint } \\
\text { Mentha spicata }\end{array}$} & 0.4 & 1.75 & I & 0 & 13.33 & $\mathrm{I}$ & 0 & 40 & II & 0 \\
\hline & 0.2 & 27.5 & III & 0 & 47.5 & III & 0 & 67.5 & IV & 0 \\
\hline & 0.1 & 42.5 & III & 0 & 50 & III & 0 & 80 & IV & 0 \\
\hline & 0.05 & 63.33 & IV & 0 & 78.33 & IV & 0 & 75 & IV & 0 \\
\hline \multicolumn{2}{|c|}{ Pearson (r) } & \multicolumn{3}{|c|}{$-0.99 * *$} & \multicolumn{3}{|c|}{$-0.97 *$} & \multicolumn{3}{|c|}{-0.93} \\
\hline \multirow{4}{*}{$\begin{array}{c}\text { Lemon } \\
\text { Citrus limon }\end{array}$} & 0.4 & 30 & II & 0 & 33.33 & II & 0 & 35.15 & II & 38.33 \\
\hline & 0.2 & 15 & $\mathrm{I}$ & 0 & 15 & $\mathrm{I}$ & 0 & 60 & III & 0 \\
\hline & 0.1 & 13.33 & $\mathrm{I}$ & 0 & 16.67 & $\mathrm{I}$ & 0 & 30 & II & 0 \\
\hline & 0.05 & 5.67 & $\mathrm{I}$ & 0 & 10 & 0 & 0 & 23.33 & I & 0 \\
\hline \multicolumn{2}{|c|}{ Pearson (r) } & \multicolumn{3}{|c|}{$0.98^{*}$} & \multicolumn{3}{|c|}{0.94} & \multicolumn{3}{|c|}{0.37} \\
\hline \multirow{4}{*}{$\begin{array}{c}\text { Aloe } \\
\text { Aloe vera }\end{array}$} & 0.4 & 14.28 & $\mathrm{I}$ & 16.67 & 10 & $\mathrm{I}$ & 26.67 & -10 & 0 & 28.33 \\
\hline & 0.2 & 23.63 & II & 0 & 10 & I & 0 & 36.67 & II & 0 \\
\hline & 0.1 & 20 & II & 0 & 13.33 & $\mathrm{I}$ & 0 & 43.33 & III & 0 \\
\hline & 0.05 & 50 & III & 0 & 53.33 & III & 0 & 66.67 & IV & 0 \\
\hline \multicolumn{2}{|c|}{ Pearson (r) } & \multicolumn{3}{|c|}{-0.79} & & -0.72 & & & -0.99 & \\
\hline & 0.4 & 23.64 & II & 31.67 & -63.33 & 0 & 83.33 & -63.33 & 0 & 96.67 \\
\hline Marjoram & 0.2 & -11.11 & 0 & 33.33 & -13.33 & 0 & 66.67 & 0 & 0 & 96.67 \\
\hline $\begin{array}{l}\text { vrlganum } \\
\text { vulgare }\end{array}$ & 0.1 & 27.59 & II & 0 & 13.33 & $\mathrm{I}$ & 11.67 & -10 & 0 & 43.33 \\
\hline vulgare & 0.05 & 63.33 & IV & 3.33 & 60.71 & IV & 3.33 & 60 & III & 6.67 \\
\hline Pearson ( $\mathrm{r}$ & & & -0.5 & & & -0.99 & & & -0.92 & \\
\hline
\end{tabular}

${ }^{1}$ PR stands for percentage repellency. 
It is high significant negative correlation in both Mint and Aloe oils ( $\mathrm{r}=-0.99 * * \&-0.79$, res), where the highest percentage of repellency at the lowest tested concentration recorded 63.33 and 50\% PR respectively at $0.05 \mathrm{~g} / 1 \mathrm{ml}$.

The results indicated that the mortality of $T$. confusum adults remarkable from the beginning of exposure to Marjoram oil, which made high concentrations of it highly toxic (acute toxicity), and the lowest concentrate was maintained with a high of PR $63.33 \%$ (class IV), $\mathrm{r}=-0.51$.

Tabulated and illustrated data showed that with the increase in exposure length, the repellent efficacy of lemon, clove, mint, aloe, and camphor oils increased. Continued positive correlation of Lemon oil and Clove during the two subsequent exposure periods, with $\mathrm{r}=0.94$ $\& 0.37$ for Lemon and $0.87 \& 0.96^{*}$ for Clove, respectively. In contrast, the Camphor oil turn into negative correlation with both Mint and Aloe $-0.34 \&-0.15,-0.97 * \&-0.92$ and -0.72 $\&-0.99 *$ after 3 and 24 hours from exposure. In contrast, the repellent efficacies of lowest concentration $0.05 \mathrm{~g} / \mathrm{ml}$ of Marjoram slightly decreased from 63.3 (class IV) to 60 (class III) with negative significant correlation after 3 hours exposure $\mathrm{r}=-0.99 *$ and negative repellency with increased percentages of mortality for the three highest concentration reach to $96.67,96.67,43.33,6.67$ respectively. The mortality of $T$. confusum adults was increased to 28.33 for Aloe oil at $0.4 \mathrm{~g} / 1 \mathrm{ml}$.

Overall, essential oils were effective against the confused flour beetle $T$. confusum, Eucalyptus camaldulensis was found to be the best effective $86.67 \%$ repellent efficacy, follow by Mentha spicata and Eugenia aromaticum, which are considered the most effective and stable in all concentrations tested during the entire exposure period. Citrus limon and Aloe vera have moderate repellent efficacy. The Origanum vulgare high lethal at the used concentrations.

\subsection{Combination effect of essential oils}

The average concentration of $0.1 \mathrm{~g} / 1 \mathrm{ml}$ was chosen as the mixing concentration at a ratio of 1: 1 for each oil against adults of $T$. confusum with three an exposure period (Table \& chart, 2).

It was indicated in (Table, 2) and (Chart, 2) the high repellent efficacy in most mixed plant oils compared to oils alone.

All treatments were Synergism effect against adults of $T$. confusum with negative PR -3.33- -3.33 and $-23.33 \%$ for Camphor + Marjoram, Camphor + Clove and Clove + Marjoram after one hour exposure, while recorded combination of Clove + Mint and Mint + Aloe the best effective $76.67 \%$ repellent efficacy, follow Clove + Aloe, Lemon + Mint and Lemon + Aloe of 73.33.63.33.63.33 \%PR, respectively. Shown moderate repellent efficacy for Camphor + Mint, Lemon + Marjoram, Lemon + Clove and Camphor + Aloe class III and II. Lemon + Camphor and Mint + Marjoram were recorded lowest $20 \& 16.67 \% \mathrm{PR}$, respectively.

The second exposure time at 3 hours, the percentage of repellent is decreased for all combination except, Camphor + Clove and Clove + Marjoram and Camphor + Marjoram moved from negative repellency to positive repellency of $40,3.33 \& 0 \% \mathrm{PR}$, addition increased of repellent efficacy for Clove + Mint and Marjoram + Aloe reach to 86.67 $\& 36.67 \%$.

At last exposure period after 24 hours from exposure, there are mixtures whose repellent activity decreases slightly such as Clove + Aloe, Mint + Aloe, Marjoram + Aloe from class IV, IV \& II to II, III and I, while others maintain and increase their high repellent activity, such as Lemon + Mint, Lemon + Marjoram, Lemon + Clove, Lemon + Aloe, and Clove + Mint, While Camphor + Mint has lost its repellency after one day of exposure. 
Assessment of Some Essential Oils and Their Mixtures as Material Repellents Against Adults of The Confused Flour Beetle, Tribolium confusum (Du Val) (Coleoptera:

Tenebrionidae)

Table 2. Percentage repellency of combination six essential ratios (1:1) against adult of $T$. confusum during three exposure times

\begin{tabular}{|c|c|c|c|c|c|c|c|c|c|}
\hline \multirow{2}{*}{$\begin{array}{l}\text { Mixture oils } \\
0.5+0.5 \mathrm{~g} / 1 \mathrm{ml}\end{array}$} & \multicolumn{3}{|c|}{1 Hour } & \multicolumn{3}{|c|}{3 Hours } & \multicolumn{3}{|c|}{24 Hours } \\
\hline & $\% \mathbf{P R}^{1}$ & Class & $\begin{array}{c}\% \\
\text { Mortality }\end{array}$ & $\%$ PR & Class & $\begin{array}{c}\% \\
\text { Mortality }\end{array}$ & $\%$ PR & Class & $\begin{array}{c}\% \\
\text { Mortality }\end{array}$ \\
\hline Lemon + Camphor & 20 & I & 1.67 & 0 & 0 & 5 & -33.33 & 0 & 10 \\
\hline Lemon + Mint & 63.33 & IV & 0 & 50 & III & 0 & 63.33 & IV & 1.67 \\
\hline Lemon + Marjoram & 46.67 & III & 0 & 30 & II & 0 & 66.67 & IV & 0 \\
\hline Lemon + Clove & 40 & II & 0 & 20 & $\mathrm{I}$ & 0 & 46.67 & III & 0 \\
\hline Lemon + Aloe & 63.33 & IV & 0 & 50 & III & 0 & 76.67 & IV & 0 \\
\hline Camphor + Mint & 56.67 & III & 0 & 23.33 & II & 0 & -6.67 & 0 & 0 \\
\hline Camphor + Marjoram & -3.33 & 0 & 1.67 & 0 & 0 & 15 & 23.33 & II & 20 \\
\hline Camphor + Clove & -3.33 & 0 & 0 & 40 & II & 0 & 18.33 & I & 5 \\
\hline Camphor + Aloe & 30 & II & 0 & 26.67 & II & 0 & 40 & II & 0 \\
\hline Clove + Mint & 76.67 & IV & 0 & 86.67 & $\mathrm{~V}$ & 0 & 66.67 & IV & 0 \\
\hline Clove + Marjoram & -23.33 & 0 & 0 & 3.33 & I & 1.67 & 60 & III & 0 \\
\hline Clove + Aloe & 73.33 & IV & 0 & 33.33 & II & 0 & 40 & II & 3.33 \\
\hline Mint + Marjoram & 16.67 & $\mathrm{I}$ & 0 & 3.33 & $\mathrm{I}$ & 0 & 46.67 & III & 3.33 \\
\hline Mint + Aloe & 76.67 & IV & 0 & 63.33 & IV & 0 & 50 & III & 0 \\
\hline Marjoram + Aloe & 21.67 & II & 1.67 & 36.67 & II & 3.33 & 20 & I & 6.67 \\
\hline
\end{tabular}

${ }^{1} \mathrm{PR}$ stands for percentage repellency

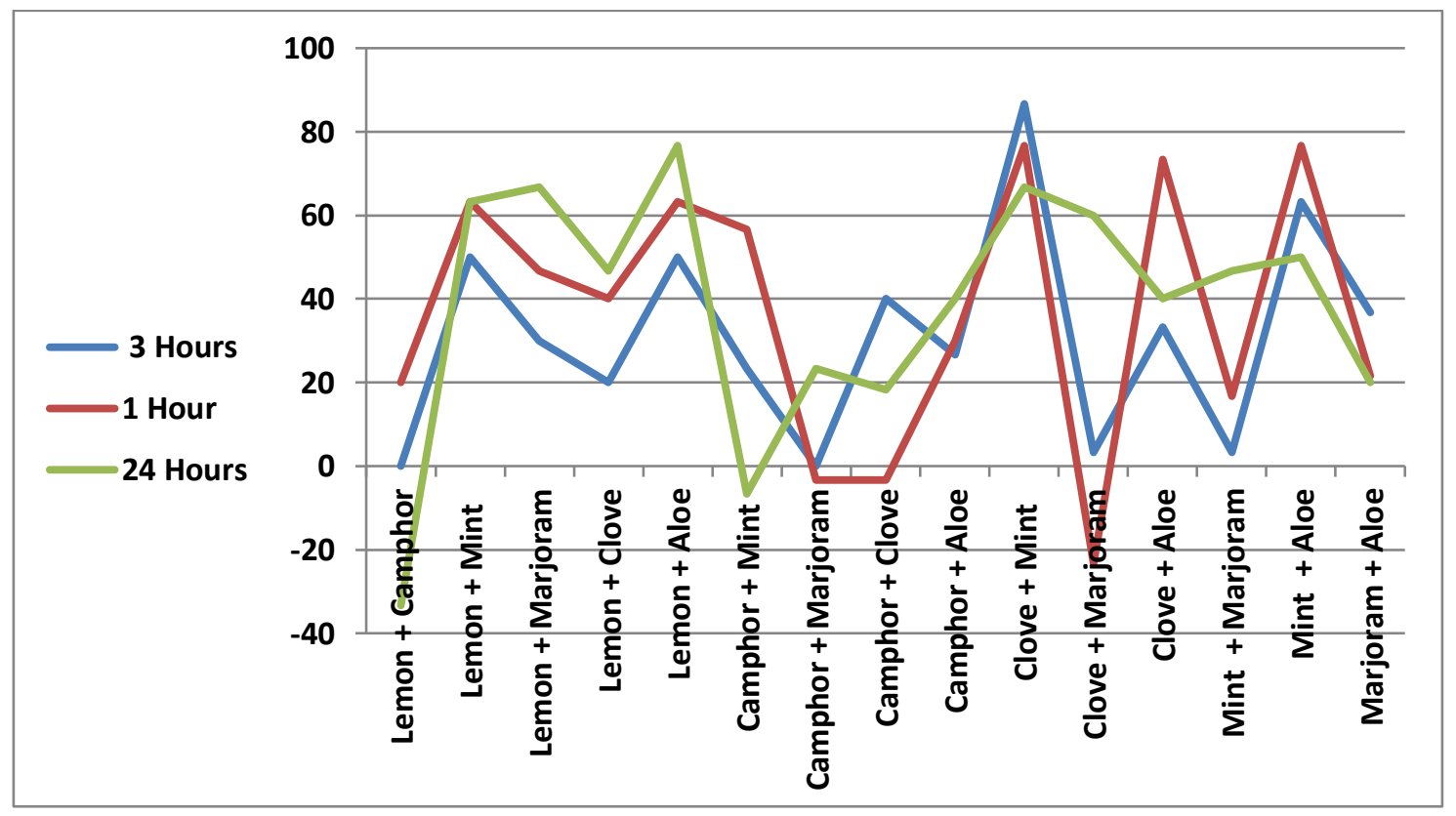

Fig 2. Diagrammatic of percentage repellency of combination six essential against adult of T. confusum during three exposure times 
Camphor + Marjoram, Camphor + Clove, Clove + Marjoram the repellant activity gradually increased, reaching its maximum repellency rate at 24 hours. It was noticed that the oil mixtures with lemon oil provided its repellant efficiency, which transferred it from a medium to a high class of repellency, exception of mixing camphor with lemon, as mixing them together inhibited the repellent effect of them.

Shown few percentage of mortality for some essential oils mixture the highest values were recorded by Camphor + Marjoram and Lemon + Camphor $20 \& 10 \%$ respectively.

Finally, the most effective mixture of Clove + Mint was shown to repel action against adults of $T$. confusum from tabulated and illustrated results, during the entire exposure period. Lemon + Aloe, Lemon + Marjoram, Lemon + Mint, and Mint + Aloe followed up. In comparison, after 24 hours, Lemon + Camphor and Camphor + Mint lost their repellent activity.

There are numerous studies about the use of plant oils for pest management, especially flour beetles. In this work found the Eucalyptus camaldulensis the best repellent at $1 \mathrm{~g} / 1 \mathrm{ml}$ against Tribolum confusum, Mentha spicata and Eugenia aromaticum are high repellents towards Tribolium confusum. Citrus limon and Aloe vera have moderate repellent efficacy, while Origanum vulgare high lethal at same used concentration. These findings are consistent with several prior researches using essential oils as a repellent for flour beetles, such as (Bhaskar Mi and Tripathi 2011) observed, Schyzygium aromaticum was highest repellant activity against Tribolium castaneum. (Ramsha et al 2019) investigated the repellent action of clove, coriander, neem and mint extracts towards Tribolium castaneum. The effects of these plant extracts have been shown to have effective insect repellent action. Coriander, accompanied by mint, was the most effective extract, while clove was less effective. The most effective concentration was 1.5 percent emphasis.
The fore-mentioned results are consistent with his findings (Salem et al 2018) at concentrations of $0.31 \mu \mathrm{L} / \mathrm{cm} 2$ and $0.078 \mu \mathrm{L} / \mathrm{cm} 2$ resp of Mentha pulegium, the repellent activity arrived to 80 and 60 percent after 1 and $24 \mathrm{~h}$ of Tribolium castaneum exposure. And (Khani and Asghari 2012) demonstrated good larvicidal efficiency to Tribolium Castaneum with Mentha longifolia oils.

Positive effects of repellent activity and larval mortality of clove oil on $T$. castaneum Larvae (Jeyasankar et al 2016).

(Ofori et al 2010) noticed the bioactivity of camphor, extracted from basil shrub essential oil, Ocimum kilimandscharicum, against Tribolium castaneum, by used contact, grain application, and repellency. Camphor was extremely poisonous in camphor-treated grain, growth of eggs and immature stages inside grains, and progeny emergence, were totally inhibited. Repellency of camphor (Pavela 2004) indicated that Origanum majorana extract was highly repellent for adults of the Colorado potato beetle (Leptinotarsa decemlineata). Repellent activity for the Amomum villosum essential oil and its four components at high concentration but the Limonene, Camphene and Camphor have high fumigant on $T$. Castaneum (Chen et al 2018).

The mixture of essential oils provided a higher repellent efficacy in these articles, which is consistent with the (pavela 2015) tested the acute toxicity effectiveness of 30 aromatic compounds and their reciprocal binary combinations against Culex quinquefasciatus larvae. In total, 435 binary combinations, of which 249 combinations had a major synergism, were tested. An important antagonistic impact on mortality was demonstrated by 74 combinations. (Lee et al 2020) found that the repellent efficacy of Origanum vulgare and Tanacetum cinerariifolium against Plodia interpunctella larvae was greatest. T. Cinerariifolium demonstrated effective repellence against the adults and larvae of Tribolum castaneum and improved repellant efficacy by combining them. 


\section{Assessment of Some Essential Oils and Their Mixtures as Material Repellents Against Adults of The Confused Flour Beetle, Tribolium confusum (Du Val) (Coleoptera: Tenebrionidae)}

(Benelli et al 2017) found that by preparing simple binary mixtures of essential oils, larvicidal efficacy can be improved against Culex quinquefasciatus, (Diptera: Culicidae), such as Satureja Montana + Aloysia citriodora at (ratio 1:1), which displayed greater larvicidal toxicity.

\section{Conclusion}

Concluded that it was observed that the confused beetle Tribolum confusum camphor, clove and mint displayed the greatest repellent behavior of all six essential oils, while the marjoram oils have a lethal effect, all individual oils have repellent activities of varying degrees against adults. Mention that $0.1 \mathrm{~g} / 1 \mathrm{ml}$ the most effective concentration. The combination of oils has synergism repellent efficacy. Lemon + Aloe, Lemon + Mint, Lemon + Marjoram and Clove + Mint are most of repellent efficacy, in contrast Lemon + Camphor is least effective.

Thus, essential oils and their mixtures are an important and safe source of insect repellents, especially flour beetle.

\section{References}

Benelli G, Pavela R, Canale A, Cianfaglione K, Ciaschetti G, Conti F, Nicoletti M, Nathan SS, Mehlhorn H, Maggi F (2017) Acute larvicidal toxicity of five essential oils (Pinus nigra, Hyssopus officinalis, Satureja montana, Aloysia citrodora and Pelargonium graveolens) against the filariasis vector Culex quinquefasciatus: Synergistic and antagonistic effects. Parasitol Int 66, 166-171.

Bennett SM (2003) Tribolium confusum (Confused Flour Beetle) and Tribolium castaneum (Rust Red Flour Beetle).

Bhaskar Mi, B, Tripathi SP (2011) Repellent Activity of Plant Derived Essential Oils against Sitophilous oryzae (Linnaeus) and Tribolium castaneum (Herbst). Singapore J Sci Res 1, 173-178.
Chen ZY, Guo SS, Cao JQ, Pang X, Geng Z, Wang Y, Zhang Z, Du SS (2018) Insecticidal and repellent activity of essential oil from Amomum villosum Lour and its main compounds against two stored-product insects. Int J Food Properties 21, 2265-2275.

Daglish GJ (2004) Effect of exposure period on degree of dominance of phosphine resistance in adults of Rhyzopertha dominica (Coleoptera: Bostrychidae) and Sitophilus oryzae (Coleoptera: Curculionidae). Pest Manag Sci 60, 822-826.

Deb M, Kumar D (2020) Bioactivity and efficacy of essential oils extracted from Artemisia annua against Tribolium casteneum (Herbst. 1797) (Coleoptera: Tenebrionidae): An eco-friendly approach. Ecotoxicol Environ Saf 189, 109988.

Feng YX, Zhang X, Yang Wang, Zhen-Yang C, Xin-Xin L, Yue Shen D, Shu-Shan D (2021) The potential contribution of cymene isomers to insecticidal and repellent activities of the essential oil from Alpinia zerumbet. Int Biodeterioration \& Biodegradation 157, 105138.

Grace OM, Simmonds MSJ, Smith GF, Wyk AE (2009) Documented Utility and Biocultural Value of Aloe L. (Asphodelaceae): A Review. Econ Botany 63, 167-178.

Holloway JC, Daglish GJ, Mayer DG (2020) Spatial Distribution and Flight Patterns of Two Grain Storage Insect Pests, Rhyzopertha dominica (Bostrichidae) and Tribolium castaneum (Tenebrionidae). Implications for Pest Manag Insects 11, 715.

Isman MB (2006) Botanical insecticides, deterrents, and repellents in modern agriculture and an increasingly regulated world. Annu. Rev Entomol 51, 45-66.

Isman MB (2020). Botanical insecticides in the twenty-frst century fulflling their promise? Annu Rev Entomol 62, 233-249.

Jeanmart S, Edmunds AJ, Lamberth C, Pouliot M (2016) Synthetic approaches to the 20102014 new agrochemicals. Bioorg Med Chem 24, 317-341. 
Jeyasankar A, Chennaiyan V, Chinnamani T (2016) Evaluation of Five Essential Plant Oils as a Source of Repellent and Larvicidal Activities Against Larvae of Tribolium castaneum(Herbst) (Coleoptera: Tenebrionidae). $J$ Entomol 13, 98-103.

Jo HJ, Park KM, Min SC, Na JH, Park KH, Han J (2013) Development of an anti-insect sachet using a polyvinyl alcohol cinnamon oil polymer strip against Plodia interpunctella. $J$ Food Sci 78, 1713-1720.

Khani A, Asghari J (2012) Insecticide activity of essential oils of Mentha longifolia, Pulicaria gnaphalodes and Achillea wilhelmsii against two stored product pests, the flour beetle, Tribolium castaneum and the cowpea weevil, Callosobruchu smaculatus. J Insect Sci 12, 10.1673/031.012.73.

Lee MY (2018) Essential Oils as Repellents against Arthropods. BioMed Res Int 6860271.

Lee HE, Hong SJ, Hasan N, Baek EJ, Kim JT, Duk Kim Y, Park MK (2020) Repellent efficacy of essential oils and plant extracts against Tribolium castaneum and Plodia interpunctella. Entomol Res 50, 450-459.

Lopez M, Jord'an M, Pascual-Villalobos M (2008) Toxic compounds in essential oils of coriander, caraway and basil active against stored rice pest. J Stored Prod Res 44, 273 278.

Mediouni Ben Jemâa J, Tersim N, Toudert KT, Khouja ML (2012) Insecticidal activities of essential oils from leaves of Laurus nobilis L. from Tunisia, Algeria and Morocco, and comparative chemical composition. J Stored Prod Res 48, 97-104.

McGovern TP, Gillenwater HB, McDonald LL (1977) Repellents for adult Tribolium confusum: mandelates [Insect pests]. J Georgia Entomol Soc 12, 79-84.

Nerio L, Olivero-Verbel J, Stashenko E (2009) Repellent activity of essential oils from seven aromatic plants grown in Colombia against Sitophilus zeamais Mostschulsky (Coleoptera). J Stored Prod Res 45, 212-214.
Ofori DO, Reichmuth C, Bekele AJ, Ali AH (2010) Toxicity and protectant potential of camphor, a major component of essential oil of Ocimum kilimandscharicum, against four stored product beetles. Int J Pest Manage 44, 203-209.

Olivero-Verbel J, Tirado-Ballestas I, Caballero-Gallardo K, Stashenko EE (2013) Essential oils applied to the food act as repellents toward Tribolium castaneum. J Stored Prod Res 55, 145-147.

Pavela R (2004) Repellent effect of ethanol extracts from plants of the family Lamiaceae on Colorado Potato Beetle adults (Leptinotars adecemlineata Say). Nation Acad Sci Lett 27, 195-203.

Pavela R (2015) Acute toxicity and synergistic and antagonistic effects of the aromatic compounds of some essential oils against Culex quinquefasciatus Say larvae. Parasitol Res 114, 3835- 3853.

Pugazhvendan SR, Elumalai K, Ross PR, Soundararajan M (2009) Repellent activity of chosen plant species against Tribolium castaneum. World J Zool 4, 188-190.

Ramsha A, Saleem KA, Saba B (2019) Repellent Activity of Certain Plant Extracts (Clove, Coriander, Neem and Mint) Against Red Flour Beetle. American Sci Res J Eng Techno and Sci (ASRJETS) 55, 83-91.

Salem N, Bachrouch O, Sriti J, Msaada K, Khammassi S, Hammami M, Selmi S, Boushih E, Koorani S, Abderraba M, Marzouk B, Limam F, Mediouni Ben Jemaa J (2018) Fumigant and repellent potentials of Ricinus communis and Mentha pulegium essential oils against Tribolium castaneum and Lasioderma serricorne. Int J Food Prop 20, S2899-S2913.

Senedecor GW, Cochran WG (1967) Statistical methods book. The Iowa State, Univ. Press. Ames. Jowa, USA, $6^{\text {th }}$ ed.

Shimomura K, Oikawa H, Kayukawa T, Asamizu S, Suzuki N, Yajima S, Tomizawaa M (2019) Repellency activity of vanillyl butyl 


\section{Assessment of Some Essential Oils and Their Mixtures as Material Repellents Against Adults of The Confused Flour Beetle, Tribolium confusum (Du Val) (Coleoptera: Tenebrionidae)}

ether is mediated by transient receptor potential vanilloid channels in the red flour beetle, Tribolium castaneum (Herbst). J Asia-Pacific Entomol 22, 916-920.

Sylvia BA Umoetok Osuagwu AN, Udo IA, Idiongette MI, Ukeh DA (2009) Effects of Azadirachta indica products on the management of Ootheca mutabilis on Telfairia occidentalis in Calabar, Southeast Nigeria. Crop Prot 28, 583-587.

Tang GB, Song BZ, Zhao LL, Sang XS, Wan, H, Zhang J, Yao Y (2013) Repellent and attractive effects of herbs on insects in pear orchards intercropped with aromatic plants. Agroforestry Systems 87, 273-285.

Trematerra P, Sciarretta A (2004) Spatial distribution of some beetles infesting a feed mill with spatio-temporal dynamics of Oryzaephilus surinamensis, Tribolium castaneum and Tribolium confusum. J Stored Prod Res 40, 363-377.

Ukeh D, Birkett M, Pickett J, Bowman A, Mordue LA (2009) Repellent activity of alligator pepper, Aframomum melegueta, and ginger, Zingiber offcinale, against the maize weevil, Sitophilus zeamais. Phytochemistry 70, 751-758.

Ukeh DA, Sylvia BA Umoetok (2011) R epellent effects of five monoterpenoid odours against Tribolium castaneum (Herbst) and Rhyzopertha dominica (F.) in Calabar, Nigeria. Crop Prot 30, 1351-1355.

Zandi- Sohani N, Hojjati M, Carbonell BÁA (2013) Insecticidal and repellent activities of the essential oil of Callistemon citrinus (Myrtaceae) against Callosobruchus maculatus (F.) (Coleoptera: Bruchidae). Neotrop Entomol 42, 89-94.

Zapata N, Smagghe G (2010) Repellency and toxicity of essential oils from the leaves and bark of Laurelia sempervirens and Drimys winteri against Tribolium castaneum. Indus. Crops and Prod 32, 405-410.

Zetter LJ, Cuperus GW (1990) Pesticide Resistance in Tribolium castaneum (Coleoptera: Tenebrionidae) and Rhyzopertha dominica (Coleoptera: Bostrichidae) in Wheat. J Econ Entomol 83, 1677-1681. 